причиной ликвидаџии местного права и изменения в культурной жизни Черниговщины с предоставлением ей особенного правового и культурного статуса.

Ключевые слова: комплектование, казацкое войско, слободские полки, казаки, принцип комплектования, военная служба, мобилизация казацкого войска, историография, методологические принцииь, малороссийские казаки, казачьи полки, социиальный статус.

\title{
HISTORIOGRAPHICAL ANALYSIS THE ORIGIN OF MALOROSSIYA COSSACKS
}

The article analizes historiographical conceptions and theories dealing with the origin of Malorossiya Cossack class. It was cleared up that there were two ideas of Malorossiya Cossacks origin: ethnic and social. Scientists share the opinion that it is Cossacks who defended Ukrainian people from foreign enemies, made an active resistance to social, national and religious oppression.

The author of the article makes an attempt to analyze the views and ideas of researchers XIX-XXI centuries about these events, understand and determine the value of the historical heritage with a modern point of view.

The principles of the manning of the Cossack army in Ukraine in the XVII century are nalizised in this article, and the internal organization of the troops, and the system of maintenance and command are considered in this article.

The author considers cultural, social and economic, political, technical and legal factors that influenced the local low abolishing and changes in the cultural life of Chernigov province giving in a specific legal and cultural status.

It is grounded that Malorossiya Cossacks were formed out of the representatives from different classes and the autochthon conceptions on Malorossiya Cossacks origin are the most evident of all.

It is reasoned out that vacant lends in the left-bank Ukraine were the neccessary condition for the development of Malorossiya Cossacks settlement.

Key words: historiography, methodological principles, malorossiyskie's cossacks, cossack's regiments, historical heritage, ethnic, social status.

УДК 34(09)

Олійник В. С., кандидат юридичних наук, старший викладач кафедри теорії та історії держави і права, конституційного права, Академія Державної пенітенціарної служби, м. Чернігів

\section{ВЕРХОВНИЙ СУД США ПІД ГОЛОВУВАННЯМ ХЬЮЗА Ч. Е. (1930-1941)}

У статті досліджено роль Верховного суду США - вищої федеральної судової інстаниії у формуванні системи права в 1930-1941 рр. (у період головування судді Хьюза Ч. Е.), а також вплив у цеей період федеральної судової влади на виконавчу й законодавчу владу та правову систему держави. Визначено роль 
Верховного суду США у формуванні конституиійного устрою США, створенні прецеденту, щзо в подальшому використовувався президентами США в їх діяльності. Запропоновано висновки і рекомендації.

Ключові слова: Верховний суд США, федеральна судова влада, «Новий курс», система права, державне втручання в економіку, виконавча влада США, законодавча влада США, президент США, Конгрес США, творення правових норм.

\section{Постановка проблеми та її зв'язок з важливими практич-} ними завданнями. Сьогодні набуває актуальності питання про можливість вступу України до Європейського Союзу. Зважаючи на це, суттєво необхідно довести рівень функціонування економіки України до рівня світових стандартів. У цьому контексті доцільно звернутися до досвіду зарубіжних держав, наприклад США, які в 1929-1933 рр. знаходилися у стані економічної кризи, але завдяки різноманітним засобам, передусім правового впливу, змогли їі подолати.

Дослідження становища США в 1930-1941 рр. є актуальним не тільки 3 огляду на те, що в цей час здійснювалися заходи подолання світової економічної кризи, але також тому, що саме тоді Верховний суд США вступив у найгостріший (за всю історію) конфлікт з вищою виконавчою владою - президентом.

Аналіз останніх досліджень та публікацій. Грунтовних комплексних наукових розробок, у яких би досліджувалася роль Верховного суду США у формуванні конституційного устрою, його вплив на правову систему держави в 1930-1941 pр. (у період головування судді Хьюза Ч. Е.), в українській правовій літературі ще не опубліковано. Щоправда, досить актуальними є результати дослідження, проведені в межах написання дисертації на здобуття наукового ступеня кандидата юридичних наук Плотнікової Т. В. «Новий курс Рузвельта Ф. Д. та еволюція цивільного права США» [1]. Однак автор, досліджуючи вплив законодавчих заходів «Нового курсу» Рузвельта Ф. Д. у стимулюванні ділової активності на розвиток цивільно-правових норм, які регулювали діяльність банківської системи, визначали принципи політики зовнішньої торгівлі, закріплювали за державою право на винахід, передбачали порядок укладання та виконання договорів, регулювали діяльність корпорацій, регламентували порядок визнання юридичної особи банкрутом [1, с. 2], не згадує про роль Верховного суду США, у цьому випадку, у створенні цивільно-правових норм, оскільки цей 
Суд здійснює також правотворчу діяльність, а судові прецеденти $є$ невід’ємним джерелом права у США.

Досить актуальною є праця Івальницької О. П. [2], в якій автор розкриває більше сутність економічного, а не правового становища США в роки економічної кризи, до того ж вона не досліджує характер політико-правового ставлення Верховного суду США до програми «Нового курсу» Рузвельта Ф. Д.

Праці радянських учених Жидкова О. А. [3], Мішина А. О. [4; 8], Борисюка В. І., Борщевської Е. Я., Веремьєвої Е. М. [5], Наришкіної Р. Л. [6] також становлять для нас інтерес, але ці автори здебільшого висловлювали гостру ідеологічну критику на адресу Головного судді Хьюза Ч. Е. та Верховного суду США.

Метою дослідження с: визначення ролі Верховного суду США - вищої федеральної судової інстанції у формуванні системи права в 1930-1941 pp. (у період головування судді Хьюза Ч. Е).

Відповідно до мети завданнями цього дослідження с: а) з'ясування дійсного характеру політико-правових відносин між федеральною судовою, виконавчою та законодавчою гілками влади в США; б) визначення впливу, в 1930-1941 pp. (у період головування судді Хьюза Ч. Е.), федеральної судової влади на виконавчу та законодавчу владу США; в ) пропозиція висновків і рекомендацій.

Виклад основного матеріалу. Верховний суд США як суд загальної юрисдикції та конституційної юстиції повинен (у разі виникнення правового спору), проаналізувавши положення законів, які на думку сторони у справі є неконституційними, визначити питання про їхню відповідність федеральній Конституції.

Світова економічна криза 1929-1933 рр., що охопила всі західні держави, призвела також і до занепаду економіки США. Головними причинами цієї кризи були високий ступінь монополізації капіталів та виробництва, ліквідація державного регулювання економічних відносин, невідповідність між темпами виробництва та зростанням заробітної плати, а звідси, перевиробництво товарів і спад попиту на них. Власники підприємств скорочували виробництво 3 метою підтримання стабільних цін, що призводило до масового безробіття [2, с. 104].

Криза у США розпочалася 3 падіння курсу акцій на НьюЙоркській біржі (24 жовтня 1929 р.). Упродовж місяця вартість 
акцій знизилася на 16 мільярдів доларів і дійшла нульової позначки, через що банки припинили виплачувати депозити і закривалися (в 1929-1932 рр. було закрито понад 5 тис. банків, тобто 20 \%). Мільйони громадян втратили свої заощадження, збанкрутувало більше 130 тис. підприємств, а промислове виробництво скоротилося на 46 \%. Різке зниження цін на сільського сподарську продукцію призвело до розорення 900 тисяч (15 \%) фермерських господарств. У кінці 1933 р. налічувалося 17 млн безробітних. У США не було державної системи соціального страхування на випадок хвороби, старості, втрати роботи тощо [2, с. 104-105].

Основний тягар подолання економічної кризи США випав на долю президента Рузвельта Ф. Д., обраного 1932 р., який розробив «Новий курс» - серію правових актів, положення яких передбачали вживання заходів, спрямованих на відновлення економіки держави. Рузвельт Ф. Д. керувався уявленням про те, що «концентрація економічної влади загрожує ідеалам демократії, а необхідними попередніми умовами політичної демократії $є$ економічна реформа, впровадження якої повинно перебороти філософію індивідуалізму та вільного ринку і забезпечити перехід втручання держави в усі сфери суспільного життя [2, с. 106, 109].

В основі програми «Нового курсу» була ідея англійського економіста Кейнса Дж. про необхідність часткового державного втручання в економіку з метою підвищення купівельної спроможності населення, його зайнятості і соціального захисту. Рузвельт Ф. Д. мав намір поставити під контроль держави великих монополістів, які в конкурентній боротьбі могли призвести до краху держави, підвищити платоспроможність населення та стимулювати виробництво [2, с. 110].

«Новий курс» складався із законів, спрямованих, по-перше, на регулювання та зміцнення кредитно-фінансової системи, було скасовано золотий стандарт, заборонено вивіз золота та обмін його на паперові гроші, надано державну допомогу банкам, дозволялося відкривати банки, визнані «здоровими», інвестиційні банки відокремлювалися від комерційних, запроваджено державне гарантування депозитних вкладів населення (до 5 тис. доларів). По-друге, введено державну систему відновлення та регулювання промислового виробництва та трудових відносин («антитрестівське» зако- 
нодавство) та обов'язкові правила Я «чесної конкуренції», які стосувалися обсягів виробництва, мінімуму заробітної плати та тривалості робочого тижня до 40 год., використання нових технологій, законодавче регулювання системи соціального страхування. Потретє, подолання аграрної кризи передбачалося шляхом визначення щорічних обсягів виробництва, що грунтується на видах сільськогосподарської продукції та паритетних цінах на неї, рефінансування фермерської заборгованості. По-четверте, 3 метою послаблення соціальної напруги, уряд створив трудові табори для безробітної молоді, 3 млн 3 яких саджали ліси, ремонтували дороги, будували мости, проводили меліорацію [2, с. 110-111].

Однак Верховний суд США, судді якого, до президентства Рузвельта Ф. Д., були призначені («за порадою та згодою Сенату») президентами-республіканцями, вважав «Новий курс» надто радикальним на той час, оскільки його положення передбачали пряме втручання держави в соціально-економічні відносини, що, на його думку, було посяганням на конституційне право приватної власності та конституційний принцип свободи договору.

Радянські науковці політико-правове ставлення Верховного суду США до «Нового курсу» поділяли на три умовні періоди: 1) 1933-1934 pp. - період «очікування»; 2) 1935-1936 рр. - період різкої конфронтації, коли суд визнав неконституційними більшість правових актів «Нового курсу»; 3) 1937-1945 рр., коли Верховний суд США визнав конституційність деяких нормативних актів соціального законодавства «Нового курсу» [4, с. 167-168].

Найвідомішою справою, розглянутою Верховним судом США в період «очікування», була «United States v. Dubilier Condenses Corp.» (1933). Верховний суд США, продовжуючи вирішувати питання, яке вперше виникло ще в 1843 р. (пов'язувалося з правом на винахід, розроблений працівниками приватних підприємств), вирішуючи спір про право держави на винахід, але створений працівниками державних підприємств, вказав, що коли «працівник у свій робочий час, працюючи 3 використанням матеріалів $\mathrm{i}$ обладнання наймача, створив та отримав патент на винахід, він зобов'язаний надати наймачеві «невиключне» право використовувати винахід, оскільки наймач, зважаючи на принцип справедли- 
вості, має право послуговуватися всім тим, у чому відображена його власність» [6, с. 68-69].

Ми погоджуємося 3 думкою Наришкіної Р. Л., що Верховний суд США розумів становище державних та приватних працівників як тотожне, оскільки «закони, рішення та адміністративна практика заперечують існування зобов'язань урядового працівника, відмінних від зобов'язань працівника приватних підприємств» [6, с. 69].

У 1935-1936 рр. Верховний суд США серією рішень, керуючись доктриною «laissez-faire» (невтручання держави у підприємництво), фактично паралізував «Новий курс», визнавши неконституційними закони, що спрямовані на подолання економічної кризи [5, с. 134-135].

У 1935 р. Верховний суд США визнав неконституційними положення основних законів «Нового курсу»: «Про відновлення національної промисловості» (НІРА), «Про банкрутство фермерів», «Про регулювання сільського господарства» (ААА), «Про охорону видобутку кам'яного вугілля», «Про банкрутство муніципальних установ» та деякі інші, які передбачали державне втручання в економіку. Положеннями цих законів обмежувалися права великих корпорацій [5, с. 135].

У січні 1935 р. рішенням у справі «Panama Refining Co. v. Ryan» Верховний суд США більшістю голосів визнав неконституційною ст. 9 (С) положення «Про незаконний видобуток нафти» закону «Про відновлення національної промисловості», яка, на думку суду, суперечила принципові розподілу влади і надавала виконавчій владі квазізаконодавчі функції дискреційного характеру [4, с. 168].

6 травня 1935 р. Верховний суд США визнав неконституційним закон «Про пенсійне забезпечення на залізничних дорогах», а 27 травня 1935 р. рішенням у справі «Schechter v. United States»закон «Про відродження промисловості» через те, що, по-перше, його положення, на думку суду, незаконно делегували законодавчі функції органам виконавчої влади, по-друге, спрямовувалися на регулювання умов праці і передбачали втручання в торгівлю між штатами [4, с. 169].

У кінці 1936 р. Верховний суд США, спираючись на доктрину «свободи договору», анулював закони Нью-Йорку та інших 
штатів, якими встановлювався розмір мінімальної заробітної плати для жінок [4, с. 171-172].

Загалом у 1935-1936 pp. Верховний суд США визнав неконституційними 11 важливих законів «Нового курсу», перешкоджаючи законодавчому санкціонуванню права федерального уряду регулювати соціально-економічні відносини [4, с. 169].

Зважаючи на рішення Верховного суду США, обгрунтовані принципом «свободи договору», спрямовані проти програми «Новий курс» (зокрема, проти закріплення за громадянами деяких соціальних прав, які нею передбачалися - О. Р.), країну охопили страйки працівників різних сфер промисловості [4, с. 172].

Негативне ставлення Верховного суду США до політики Рузвельта Ф. Д. було висловлене 1935 р. його рішенням у справі «Humphrey's Exacutor v. United States», яким суд постановив, що президент не може одноособово, на підставі власного розсуду, звільняти членів Федеральної торгової комісії до закінчення строку їхніх повноважень, крім випадків, якщо такі, відповідно до закону, яким була створена Комісія, «недбало ставилися до посадових обов'язків чи зловживали посадою». Цим рішенням посадові особи, призначені Конгресом (відповідно до розділу 8 ст. 1 Конституції повинні сприяти виконанню законів - О. Р.), захищалися від довільного відсторонення «за бажанням глави виконавчої влади» [4, с. 65-66].

На думку Верховного суду США, створені Конгресом «квазісудові» та «квазізаконодавчі» агентства (яким була зазначена Комісія - О. Р.) повинні були здійснювати повноваження незалежно від президента, а дострокове усунення з посад було можливим лише $з$ причин, вказаних у законі, який передбачав їхнє створення. Отже, президент, як вказав Верховний суд США, мав право достроково відстороняти від посади лише «purely executive officers», тобто федеральних посадових осіб, які повністю підпорядковувалися виконавчій владі [4, с. 66].

Вказаний судовий спір виник унаслідок конфлікту між Рузвельтом Ф. Д. та республіканцем Хамфрі В. - членом Федеральної торгової комісії, яка як незалежний орган перешкоджала (в правозастосовчій сфері) реалізації програм «Нового курсу», а Верховний суд США (одностайним рішенням) позбавив прези- 
дента права звільняти членів незалежних агентств, які фактично були креатурою законодавчої влади (але виконували функції виконавчої влади - О.Р.) [4, с. 66].

Рузвельт Ф.Д., незадоволений рішеннями Верховного суду США, що перешкоджали впроваджувати «Новий курс», 5 лютого 1937 р. звернувся до Конгресу зі спеціальною заявою, в якій виклав план реформування суду (збільшення кількості суддів 39 до 15). План напередодні складався таємно за участі Генерального атторнея США Каммінгса X. і трьох помічників з Міністерства юстиції [10, с. 49-50]. Якщо Конгрес прийняв би пропозицію Рузвельта до уваги, були б внесені відповідні зміни до закону «Про судоустрій», а президент згідно зі ст. 3 Конституції призначив би, «за порадою та згодою» Сенату, своїх прибічників. Проте більшість Конгресу, навіть демократи - прихильники Рузвельта, побачили в його пропозиції «відверте посягання на незалежність суддів 3 боку президента» [3, с. 12], а «незалежність судової влади була визнана більшою цінністю, ніж економічна необхідність» [7].

Ми погоджуємося 3 думкою російських учених Борисюка В. І., Борщевської Е. Я. та Веремьєвої Е. М., що визнання основних правових актів «Нового курсу» неконституційними не означало краху політики Рузвельта у сфері регулювання економічних відносин. Зважаючи на ставлення Верховного суду США до «Нового курсу», Рузвельт був змушений змінити деякі положення цієї програми для того, щоб вона відповідала федеральній Конституції у тому баченні, як розуміє іiі Верховний суд. У випадку ж, якщо б президент не вніс деяких корективів до «Нового курсу», його реалізація б залишалася під питанням [5, с. 148].

Отож, Рузвельт Ф. Д. відмовився від прямого урядового втручання в господарські відносини підприємств, але федеральний уряд мав право надавати допомогу господарюючим суб'єктам, якщо вони ії потребують.

Зважаючи на поступку Рузвельта Ф. Д., 25 березня 1937 p. Верховний суд США прийняв рішення (справа «West Coast Hotel Co v. Parrish»), в якому визнав конституційним закон Вашингтона, що передбачав мінімальну заробітну плату для жінок і був ідентичний законові Нью-Йорку, який у кінці 1936 р. визнано неконституційним. Своїм рішенням Верховний суд США визначив, що 
«свобода, яка випливає з принципу «свободи договору», може обмежуватися, але тільки шляхом належної процедури» [4, с. 173].

3 середини 30-х pp. ХХ ст. Верховний суд США почав визнавати необхідність пристосовувати концепцію «матеріальної належної правової процедури» до зростаючого державного втручання в економіку (щоправда із застереженнями) [5, с. 135-136].

Відповідно до теорії американського конституційного права всі загальнополітичні повноваження федерального уряду мають «екстра конституційний» характер, що й було підкреслено 1936 p. у рішенні Верховного суду США в справі «United States v. Curtiss - Wright Export Corp» (написане суддею Сазерлендом В.): « ...надання федеральному урядові повноважень зовнішнього суверенітету не залежить від положень Конституції. Право оголошувати та вести війну, укладати мир, міжнародні договори, підтримувати дипломатичні відносини 3 іншими суверенними державами повинно надаватися федеральному урядові, оскільки супутні державності, навіть не зазначені у Конституції, права i повноваження США як члена сім’ї націй рівні правам і повноваженням інших членів міжнародної спільноти. В іншому випадку США не були б повною мірою суверенною державою. Право на територію через іiі відкриття чи окупацію, право вислання небажаних іноземців безпосередньо не передбачені Конституцією, але існують як невід'ємні та невіддільні від національного суверенітету» $[9$, с. 121].

Суддя Сазерленд В. керувався тим, що з моменту здобуття незалежності до прийняття Конституції штати володіли «внутрішнім суверенітетом», а «зовнішній суверенітет» належав Союзові штатів спільно, а не кожному штатові окремо [8, с. 121].

У квітні 1937 р. Верховний суд США рішенням у справі «National Labor Relation Board v. Jones Laughlin Steel Corporation» визнав конституційним «Національний акт про трудові відносини», який становив основу соціально-трудового законодавства Рузвельта Ф. Д. [4, с. 173].

Цим рішенням Верховний суд США розширив владу Конгресу від регулювання торгівлі до регулювання ділової практики підприємств, які брали участь у торгівлі між штатами. Корпорація «Jones Laughlin Steel», яка була однією з найбільших стале- 
ливарних компаній, порушивши положення федерального закону «Про трудові відносини» 1935 р. (законом передбачалося створення профспілок і укладення колективних договорів), звільнила 10 робітників за участь у профспілковій діяльності та відмовилася виконувати наказ Національного управління з трудових відносин і повторно брати звільнених працівників. Коли спір потрапив на вирішення Верховного суду США, він повинен був визначити, чи має право Конгрес регулювати «місцеву» діяльність компаній, які беруть участь у торгівлі між штатами, та діяльність, яка здійснюється в межах одного штату. Представники корпорації пояснювали, що умови на іiі заводі не впливали на торгівлю між штатами, а отже, не могли регулюватися Конгресом. Верховний суд США рішенням зобов'язав корпорацію поновити на роботі звільнених працівників, вказавши, що «визнання права працівників на самоорганізацію і висунення своїх представників для ведення переговорів, укладення колективного договору є необхідною умовою стабільності промисловості» [9].

Верховний суд США 1937 р. визнав конституційність вдруге прийнятого закону «Про банкрутство фермерів» та законів «Про регулювання трудових відносин на залізниці», «Про національні трудові відносини» (закон «Вагнера») [5, с. 136].

У кінці 30-х рр. ХХ ст. Верховний суд США, на думку політолога Даля Р., розпочав виробляти «конституційні підстави новим повноваженням національного уряду, які використовувалися наступними президентами в процесі реалізації їхніх програм» [5, c. 152].

У кінці 30-х рр. ХХ ст. пішли у відставку двоє консервативно налаштованих суддів Верховного суду США - Ван-Девантер У. і Сазерленд Дж., а їхні посади обійняли Блек Х. і Рід С., які активно підтримували Рузвельта Ф. Д., а до 1943 р. Верховний суд США взагалі поповнився ліберально налаштованими суддями (3 колишніх дев'яти суддів залишився Робертс О.) [4, с. 174].

Ще у 1928 р. Хьюз Ч. Е. писав, що «у Верховному суді США, як і в маленькому колективі здібних людей з рівною владою в прийнятті рішень, дійсна позиція і вплив Головного судді залежить від його вміння та здібностей знаходити спільну мову з іншими суддями» [3, с. 19]. Історії були відомі «сильні» головні 
судді (Маршал Дж. у ХІХ ст., Хьюз Ч. Е. та Уоррен Е. в ХХ ст.), які істотно вплинули на формування думок інших суддів цього суду та його рішення загалом, тобто тоді, коли більшість рішень суду були одноголосними.

Отже, в 1930-1941 рр. особливо помітно виявляється вплив Верховного суду США на формування системи права, творення правових норм, які регламентували підприємницьку діяльність, трудові відносини, відносини власності. Навіть незважаючи на доволі гострий конфлікт між президентом і Верховним судом США, все ж Конгрес не втрутився у відносини виконавчої та судової влад, хоча міг це зробити - шляхом прийняття федерального закону, яким би збільшилася кількість суддів 39 до 15, як цього просив Рузвельт Ф. Д., чи внесення відповідної поправки до Конституції, якою б анулювалося рішення суду. Більше того, в цей час виявляється помітний вплив судової влади на виконавчу, оскільки, врахувавши думку Верховного суду США, Рузвельт Ф. Д. був змушений пристосувати деякі положення програми «Нового курсу» до того, як розуміє Конституцію Верховний суд США.

Висновки. Підбиваючи підсумки, пропонуємо такі висновки і рекомендації:

1. Позиція Верховного суду США в 1935-1937 pp. у період головування в ньому Хьюза Ч. Е. щодо способів та засобів подолання наслідків економічної кризи в США кардинально не збігалася з позицією президента США Рузвельта Ф. Д.

2. У 1935-1936 pp. Верховний суд США серією рішень, керуючись доктриною «laissez-faire» (невтручання держави у підприємництво), фактично паралізував «Новий курс», визнавши неконституційними закони, спрямовані на подолання економічної кризи.

3. У кінці 30-х pp. ХХ ст. Верховний суд США розпочав виробляти конституційні підстави новим повноваженням національного уряду, які використовувалися наступними президентами в процесі реалізації їхніх програм.

4. У 1935-1937 рр. виявляється помітний вплив судової влади США на виконавчу.

5. Досвід США щодо відносин гілок влади, їхньої реальної незалежності, який можна побачити на прикладі конфлікту Верховного суду та президента США під час економічної кризи в 
США, може бути корисним у ході вироблення шляхів подолання економічної та політичної кризи в сучасній Україні.

\section{Список використаних джерел}

1. Плотнікова Т. В. «Новий курс» Рузвельта Ф. Д. та еволюція цивільного права США: автореф. дис. ... канд. юрид. наук: 12.00.01 / КДУ ім. Т. Шевченка. Київ, 1998. 17 с.

2. Івальницька О. П. Новітня історія країн Свропи та Америки. 1918-1945 рр.: навчальний посібник для студ. вищ. навчальних закладів. Вінниця: Фоліант, 2004. 464 с.

3. Жидков О. А. Верховный суд США: право и политика /отв. ред. Мишин А. А. Москва: Наука, 1985. 221 с.

4. Конституция США: история и современность /ред. Мишина А. А., Языкова Е. Ф., Николайчика В. М. Москва: Юрид. лит., 1988. 320 с.

5. Борисюк В. И., Борщевская Е. Я., Веремьева Е. М. и др. Политические институты США: История и современность /отв. ред. Борисюк В. И.; АН. СССР. Ин-т США и Канады. Москва: Наука, 1988. 271 с.

6. Нарышкина Р. Л. США: Государство и частный сектор: Гражданско-правовые отношения / АН. СССР. Ин-т США и Канады. Москва: Юрид. лит, 1976. 128 с.

7. Верховный суд США. URL: http://ru.wikipedia.org/wiki/ \%D0 \%92 $\% \mathrm{D} 0 \% \mathrm{~B} 5 \% \mathrm{D} 1 \% 80 \% \mathrm{D} 1 \% 85 \% \mathrm{D} 0 \% \mathrm{BE} \% \mathrm{D} 0 \% \mathrm{~B} 2 \% \mathrm{D} 0 \% \mathrm{BD}$.

8. Мишин А. А. Принцип разделения властей в конституционном механизме США. Москва: Наука, 1984. 191 с.

9. Знаменательные решения.

URL: http://usinfo.state.gov/journals/itdhr/0405/ijdr/decisions.htm.

10. Власихин В. А. Служба обвинение в США: закон и политика. Москва: Юрид. лит., 1981. 176 с.

\section{ВЕРХОВНЫЙ СУД США ПОД РУКОВОДСТВОМ ХЬЮЗА Ч. Э. (1930-1941)}

В статье исследовано роль Верховного суда США - высшей федеральной судебной инстанции в формировании системы права в 1930-1941 г2. (в период председательства судьи Хьюза Ч. Э.), а также влияние в этот период федеральной судебной власти на исполнительную и законодательную власть и правовую систему государства. Также определена роль Верховного суда США в формировании конституционного устройства США, создании прещедента, который в дальнейшем использовался президентами США в их деятельности. Предложено выводы и рекомендации.

Ключевые слова: Верховный суд США, федеральная судебная власть, «Новый курс», система права, государственное вмешательство в экономику, 
исполнительная власть США, законодательная власть США, президент США, Конгресс США, создание правовых норм.

\section{SUPREME COURT OF THE USA UNDER THE DIRECTION OF HUGHES Ch. E. (1930-1941)}

The role of Supreme Court of the USA is investigated in the article - to the higher federal judicial instance in forming of the system of right in 1930-1941 (in the period of chairmanship of judge Hughes Ch. E.), and also influence in this period of federal department judicial on executive and legislative power and legal system of the state. The role of Supreme Court of the USA is also determined in forming of constitutional device of the USA, creation of precedent that in future was used by Presidents of the USA in their activity. Conclusions and recommendations are offered.

There is research of position the USA in 1930-1941 it is actual not only because of that at this time measures were conducted on overcoming of world economic crisis, but also because Supreme Court of the USA entered into a peracute (for all history) conflict with executive sovereignly - President.

Supreme Court as general and constitutional justice court, must (in case of origin of legal dispute) analysing positions of laws that in opinion of side in business are unconstitutional to define a question about their accordance of federal Constitution.

So there is a necessity to find out, going round ideological conclusions, real historical and legal role of Supreme Court of the USA chaired by Hughes Ch. E. in forming of the system of right constitutional mode, and also about actual character of political and legal mutual relations between federal judicial, executive and legislative authorities.

Key words: Supreme Court of the USA, federal department judicial, "New Deal» of President F. D. Roosevelt, system of right, state interference with an economy, executive power of the USA, legislature of the USA.

УДК 340.12

Співак B. B., кандидат філософських наук, докторант Національної музичної академії України імені П. І. Чайковського, м. Київ

\section{ПОЛІТИКО-ПРАВОВІ КАТЕГОРІЇ ЯК МАРКЕР ІДЕНТИЧНОСТІ В СПАДЩИНІ АНТОНІЯ РАДИВИЛОВСЬКОГО}

У статті досліджено проблему політичної ідентичності Антонія Радивиловського на підставі аналізу політико-правового категоріального апарату філософської складової його проповідницької спадщчини. Зроблено висновок про еклектичність його політичного світогляду, в якому поєднуються образи та категорї політичного життя Русі-України, Речі Посполитої, Війська Запо- 